\title{
ETNOBOTANI TUMBUHAN FAMILY ARECACEAE DI KOTA TARAKAN
}

\section{Ethnobotany Study of Arecaceae in Tarakan}

\author{
Yoga Noval Kurniawan*a, Nuraini ${ }^{\text {a }}$, Kamelia ${ }^{\text {a }}$, Resti Mantang ${ }^{\text {a }}$, Zulfadli ${ }^{\text {b }}$, Darius Rupa ${ }^{\text {b }}$ \\ a Mahasiswa Pendidikan Biologi/Universitas Borneo Tarakan, Tarakan, Kaliamntan Utara, Indonesia \\ b Dosen Pendidikan Biologi/Universitas Borneo Tarakan, Tarakan, Kaliamntan Utara, Indonesia \\ ${ }^{*}$ Corresponding author: Jl. Amal Lama, Tarakan Timur, Tarakan, Kalimantan Utara, 77123, Indonesia. E-mail: yoganoval8@gmail.com
}

\begin{abstract}
Abstrak
Etnobotani adalah cabang ilmu yang mempelajari hubungan manusia dengan tumbuhan dan lingkungannya.Tumbuhan Arecaceae adalah salah satu family tumbuhan terpenting bagi manusia yang jenisnya banyak digunakan dalam kehidupan sehari-hari, misalnya sebagai bahan kerajinan, makanan, minuman, obat tradisional, hiasan, bahan bangunan, dan sebagainya. Bagian tumbuhan yang dimanfaatkan oleh masyarakat terdiri dari akar, batang, daun, bunga dan buah. Kota Tarakan merupakan salah satu kota yang banyak memanfaatkan family tersebut. Pemanfaatan family ini diantaranya digunakan sebagai bahan pangan, obat-obatan dan lain sebagainya. Akan tetapi, saat ini family tersebut di kota Tarakan hanya beberapa kelompok masyarakat saja yang masih memanfaatkannya secara tradisional. Penelitian ini berguna untuk memberikan informasi kepada masyarakat modern mengenai jenis kelas Arecaceae yang ada di Tarakan dan pemanfaatanya oleh masyarakat secara tradisional.Penelitian ini dilakukan pada tanggal 8 Oktober 2019 dan berlangsung selama dua bulan yaitu dari bulan Oktober sampai bulan November 2019.Alat dan bahan yang digunakan yaitu kamera, alat tulis dan lembar observasi.Objek penelitian ini adalah jenis tumbuhan Arecaceae yang dimanfaatkan oleh masyarakat Kota Tarakan. Metode yang digunakan dalam penelitian ini yaitu crution atau jelajah, observasi dan wawancara. Teknik pengambilan responden menggunakan snowball sampling. hasil yang didapatkan pada penelitian ini yaitu jenis-jenis tumbuhan yang termasuk kedalam family Arecaceae yang ditemukan adalah Cocus nucifera, Areca catechu, Chrysalidocarpus lutescens, Elaeis gulneensis, Arenga pinnata, Zalaca edulis. Tumbuhan tersebut di masyarakat kota Tarakan dimanfaatkan sebagai bahan pangan, obat tradisional dan lainnya
\end{abstract}

\section{Kata kunci}

Etnobotani, Arecaceae, Tarakan 


\begin{abstract}
Ethnobotany is a branch of interdisciplinary science that studies of human relations with plants and their environment. Arecaceae plant is one of the most important plant families for humans that is widely used in daily life, for example as a craft material, food, drink, traditional medicine, decoration, building materials, and so on. Parts of plants used by the community consist of roots, stems, leaves, flowers, and fruit. Tarakan city is one of the cities that many use this family. The use of this family is as food, medicine, and others. However, at this time, this family in Tarakan city is only a few community groups who still use it traditionally. This research is useful to provide information to modern society about the types of Arecaceae classes that exist in Tarakan and their traditional use. This research conducted on October 8, 2019, and lasted for two months, from October to November 2019. The tools and materials used are cameras, stationery, and observation sheets. The object of this research is Arecaceae plant species that are utilized by the people of Tarakan City. The method used in this study is crucial or explore, observation, and interviews. The technique of taking respondents using snowball sampling.the results obtained in this study are the types of plants that belong to the Arecaceae family found that are Cocus Nucifera, Areca catechu, Chrysalidocarpus lutescens, Elaeis gulneensis, Arenga pinnata, Zalaca edulis. These plants in the society of Tarakan are used as food, traditional medicine, and others
\end{abstract}

Keywords

Ethnobotany, Arecaceae, Tarakan

\title{
Pendahuluan
}

Etnobotani adalah cabang ilmu interdispliner yang mempelajari hubungan manusia dengan tumbuhan dan lingkungannya (Baroto 2004 dalam Suryadarma 2008).Etnobotani menekankan pada berbagai tumbuhan yang dimanfaatkan oleh masyarakat sehari-hari sebagai sandang, pangan, papan bahkan obat tradisional (Listiani \& Abrori, 2017). Kajian terkait etnobotani banyak di lakukan pada beberapa family, misalnya family Arecaceae.

Menurut Siregar (Nuryanti, et al. 2015) mengatakan bahwa tumbuhan Arecaceae adalah salah satu family tumbuhan terpenting bagi manusia yang banyak dipakai dalam kehidupan sehari-hari, misalnya sebagai bahan kerajinan, makanan, minuman, obat tradisional, hiasan, bahan bangunan, dan sebagainya. Bagian tumbuhan yang dimanfaatkan oleh masyarakat terdiri dari akar, batang, daun, bunga dan buah (Wardah 2003 dalam Yenni 2017).Pemanfaatan jenis Arecaceae yang sangat luas ternyata tidak diketahui oleh banyak masyarakat.

Salah satu wilayah yang tidak terlepas dari pemanfaatan family Arecaceae adalah kota Tarakan. Kota Tarakan merupakan salah satu kota yang banyak memanfaatkan family tersebut. Pemanfaatan family ini diantaranya digunakan sebagai bahan pangan, obat-obatan dan lain sebagainya. Akan tetapi, saat ini family tersebut di kota Tarakan hanya beberapa kelompok masyarakat saja yang masih memanfaatkannya secara tradisional. Penelitian ini 


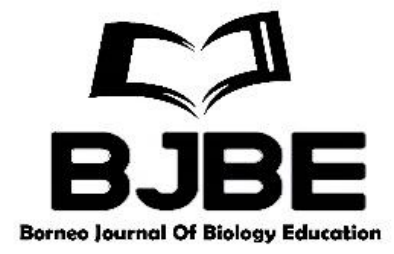

berguna untuk memberikan informasi kepada masyarakat modern mengenai jenis kelas Arecaceae yang ada di Tarakan dan pemanfaatanya oleh masyarakat secara tradisional.

\section{Material dan metode}

Penelitian ini dilakukan selama tiga bulan yaitu dari bulan Oktober sampai bulan Desember 2019. Penelitian yang dilakukan terdiri dari tahap penentuan responden, wawancara responden dan pengolahan data yang telah diperoleh.

Alat-alat yang digunakan dalam penelitian yaitu: kamera, alat tulis dan lembar observasi. Objek penelitian ini adalah jenis tumbuhan Arecaceae yang dimanfaatkan oleh masyarakat Kota Tarakan.

Metode yang digunakan dalam penelitian ini yaitu crution atau jelajah, observasi dan wawancara. Teknik pengambilan responden menggunakan snowball sampling. Pada penelitian ini diperoleh responden sebanyak 100 orang. Data yang telah diperoleh kemudian dianalisis secara deskriptif kualitatif berdasarkan hasil wawancara.

Penelitian dilakukan dengan melakukan jelajah disekitaran jalan utama dan di beberapa lokasi yang dijumpai Family Arecacea. Selanjutnya penentuan responden dengan menggunakan metode snowball sampling. Tiap responden akan diberi pertanyaan untuk mengetahui informasi mengenai tumbuhan dan pemanfaatan Arecaceae serta cara pengolahan yang selama ini digunakan oleh masyarakat Kota Tarakan.

Proses pengambilan sampel tumbuhan dilakukan di lapangan dengan cara memotret tumbuhan Arecaceae yang ditemukan. Selanjutnya dilakukan identifikasi jenis Arecaceae.

Analisis data pemanfaatan tumbuhan Arecaceae oleh masyarakat Kota Tarakan yaitu secara: a) Deskriptif, yaitu menggambarkan jenis-jenis tumbuhan Arecaceae yang dimanfaatkan oleh masyarakat Kota Tarakan. b) Tabulasi yaitu dengan menampilkan tabel dari jenistumbuhantersebut, bagian organ yang dimanfaatkan dan manfaat organ tersebut terhadap masyarakat Kota Tarakan.

\section{Hasil dan Diskusi}

Hasil dari observasi dan wawancara dijumpai berbagai jenis dari famili Arecaceae (tabel 1).Selain itu juga didapatkan bagian organ yang dimanfaatkan dan pemanfaatan organ tersebut sangat beragam misalnya sebagai bahan pangan, papan, hiasan, karya seni dan obatobatan.

Tabel 1.Hasil Pengamatan dan wawancara 100 Warga Kota Tarakan

$\begin{array}{lll}\text { Jenis Tumbuhan } & \begin{array}{c}\text { Bagian yang } \\ \text { dimanfaatkan }\end{array} & \text { Dimanfaatkan sebagai }\end{array}$

\begin{tabular}{llll} 
& Daun & - & Dibuat anyaman ketupat \\
& & - & Dibuat atap rumah \\
\cline { 2 - 3 } $\begin{array}{c}\text { Kelapa (Cocus } \\
\text { nucifera })\end{array}$ & Buah & Dimakan \\
& & - Dibuat menjadi minyak \\
& & - Dijadikan campuran masakan, kue \\
& & dan minuman \\
\hline Air Buah & - & Dimanfaatkan sebagai minuman \\
& & obat ketika keracunan/alergi \\
\hline
\end{tabular}




\begin{tabular}{|c|c|c|c|}
\hline \multirow[t]{7}{*}{ Borneo lournal of Biology Education } & \multicolumn{3}{|c|}{$\begin{array}{r}\text { Vol. } 2 \text { No. } 1,2020 ; \text { pp. } 16- \\
\text { P-ISSN: 2715-6826 (print); E-ISSN: } 2714-6073 \text { (onlin } \\
\text { Received: } 3 / 01 / 20 \\
\text { Revised: } 27 / 02 / 20 \\
\text { Accepted: } 5 / 03 / 20\end{array}$} \\
\hline & & & $\begin{array}{l}\text { Biasa digunakan untuk } \\
\text { menyembuhkan penyakit kerumut }\end{array}$ \\
\hline & Lidi & - & Sapu lidi \\
\hline & Pelepah & - & Kayu bakar \\
\hline & Batok & & $\begin{array}{l}\text { Karya seni } \\
\text { Mainan tradisional } \\
\text { Dijadikan arang }\end{array}$ \\
\hline & Umbut & & $\begin{array}{l}\text { Dijadikan sayur. Cara } \\
\text { pengolahannya umbut pohon } \\
\text { kelapa dipotong kecil-kecil lalu } \\
\text { direbus }\end{array}$ \\
\hline & Batang & - & $\begin{array}{l}\text { Digunakan dalam pembuatan } \\
\text { jembatan }\end{array}$ \\
\hline \multirow{3}{*}{ Pinang (Areca catechu) } & Buah & - & $\begin{array}{l}\text { Dijadikan obat tradisional } \\
\text { Dijadikan obat sakit kepala dengan } \\
\text { cara buah pinang dibakar } \\
\text { kemudian di hirup asapnya } \\
\text { Campuran makan sirih } \\
\text { Digunakan untuk membersihkan } \\
\text { dan menguatkan gigi dengan cara } \\
\text { dicampur dengan kapur dan dapat } \\
\text { diolah menjadi sayur. } \\
\text { Dibuat menjadi jamu }\end{array}$ \\
\hline & Batang & & $\begin{array}{l}\text { Digunakan dalam lomba panjat } \\
\text { pinang } \\
\text { Jembatan } \\
\text { Saluran air, batang pinang dibelah } \\
\text { memanjang kemudian bagian } \\
\text { dalamnya dibuang. }\end{array}$ \\
\hline & Pelepah & & $\begin{array}{l}\text { Dipakai untuk memandikan wanita } \\
\text { hamil }\end{array}$ \\
\hline \multirow{3}{*}{$\begin{array}{c}\text { Palem } \\
\text { (Chrysalidocarpus } \\
\text { lutescens) }\end{array}$} & Buah & & $\begin{array}{l}\text { Untuk obat sakit kepala, cara } \\
\text { penggunaannya yaitu ditumbuk } \\
\text { lalu dikeringkan }\end{array}$ \\
\hline & Daun & - & Anyaman \\
\hline & Pohon & & Dijadiakan tanaman hias \\
\hline \multirow{4}{*}{$\begin{array}{l}\text { Kelapa sawit (Elaeis } \\
\text { gulneensis) }\end{array}$} & Batang & & $\begin{array}{l}\text { Batang sawit yang muda dapat } \\
\text { diolah menjadi sayur }\end{array}$ \\
\hline & Buah & & $\begin{array}{l}\text { Dijadikan pakan ternak. } \\
\text { Diolah menjadi minyak sawit. }\end{array}$ \\
\hline & Biji & & $\begin{array}{l}\text { Biji kelapa sawit yang kering dapat } \\
\text { dimanfaatkan sebagai bahan bakar. }\end{array}$ \\
\hline & Pohon & - & Dijadiakan tanaman hias \\
\hline Aren (Arenga pinnata) & Buah & - & Dijadiakan kolang kaling \\
\hline
\end{tabular}




\begin{tabular}{llll} 
& Lidi & - & Sapu lidi \\
\cline { 2 - 3 } & Nira & - Gula aren \\
& Batang & - & Minuman ballo (Tuak) \\
\cline { 2 - 3 } & & Saluran air sama seperti batang \\
& Binang \\
\hline \multirow{2}{*}{ Salak (Zalaca edulis) } & & - Dimakan \\
& & - & Dijadikan manisan \\
\cline { 2 - 3 } & Pelepah & - & Joran (pancing tradisional) \\
\hline
\end{tabular}

Tumbuhan Arecaceae yang beragam dapat dijumpai dikota Tarakan diduga karena habitat yang cocok untuk tumbuh dan berkembang di kota Tarakan. Kota Tarakan memiliki suhu udara minimum rata-rata $24,8^{\circ} \mathrm{C}$ dan maksimum $31,4^{\circ} \mathrm{C}$ (BMKG Kota Tarakan). Menurut Jihad (2012) suhu yang ideal bagi family Aracaceaeyaitupada suhu $20^{\circ} \mathrm{C}-200^{\circ} \mathrm{C}$.

Menurut Siregar (2005), tumbuhan Arecaceae adalah salah satu family tumbuhan terpenting bagi manusia yang banyak dipakai dalam kehidupan sehari-hari, misalnya sebagai bahan kerajinan, makanan, minuman, obat tradisional, hiasan, bahan bangunan, dan sebagainya. Menurut Tjitrosoepomo (1983), tumbuhandari family arecaceae memiliki kegunaan antara lain sebagai sumber karbohidrat, baik dalam bentuk pati maupun gula, sumber minyak (sudah sejak lama masyarakat Indonesia memanfaatkan kelapa untuk membuat minyak goreng), sumber bahan anyaman, rotan merupakan bahan anyaman yang berkualitas tinggi. Beberapa jenis palem juga menghasilkan daun yang dapat dianyam, sumber bahan bangunan, ada jenis-jenis palem yang mempunyai batang yang kuat untuk pengganti kayu, sumber bahan penyegar, (misalnya buah pinang sebagai bahan untuk menyirih), dan sebagai tanaman hias. Pemanfaatan tumbuhan Arecaceae di kota Tarakan saat ini terbilang belum maksimal. Berdasarkan narasumber, Cocus nucifera di kota Tarakanpemanfaatannya hanya sebatas buah yang di konsumsi, air buah yang dijadikan minuman obat ketika keracunan/ alergi, air buah kelapa memiliki kandungan mineral alami dan protein berkualitas tinggi dan sangat baik untuk pertumbuhan dan perbaikan sel-sel dalam tubuh. Daun yang digunakan untuk membungkus ketupatdan, lidi digunakan sebagai sapu, pelepah dijadikan kayu bakar serta batok yang dijadikan mainan tradisional dan arang (Tabel 1).Pemanfaatan tersebut masih tergolong standar karena $C$. nucifera memiliki manfaat yang masih banyak. Menurut Roswita (2018),bagi masyarakat Aceh Cocus nucifera memiliki manfaat lain yaitu buah yang dimanfaatkan sebagai obat panas, obat mata, perawatan rambut, obat nyeri pinggang, air kelapa tuanya dapat digunakan untuk menghilangkan flek diwajah dan radang tenggorokan.Menurut Pratiwi (2013), bagi masyarakat Denpasar batang $C$. nucifera kelapa dapat digunakan sebagai alat-alat rumah tangga. Misalnya sendok, garpu, mangkok, dan tempat lilin. Menurut Oktavia (2017), bagi masyarakat Bali minyak kelapa dapat digunakan sebagai alat penyubur rambut, obat sakit gigi dan air kelapa muda dapat digunakan sebagai campuran tutuh (larutan aromatik) untuk pereda sakit kepala.

Selain C. nucifera, jenis Areceace lain yang didapat yaitu Pinang (Areca catechu).Pinang merupakan tanaman yang tidak seperti tanaman kelapa, bagian yang paling banyak dimanfaatkan oleh masyarakat adalah buahnya yang keras, pinang yang biasanya di pakai untuk bahan menginang atau makan sirih, dan masyarakat beranggapan pinang berkhasiat menguatkan gigi, (Suryadarma, 2008). Pinang juga dapat menghasilkan uang bagi masyarakat, pinang yang telah tua dijemur, kemudian dipisahkan dari kulitnya dan dijual 


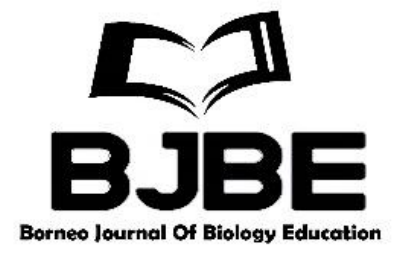

kepasar pada agen pinang tidak sama seperti kelapa, bagian yang paling banyak dimanfaatkan oleh masyarakat adalah buahnya yang keras (Silvia et al, 2017).Berdasarkan hasil pengamatan dan wawancara beberapa warga didapatkan pemanfaatan Areca catechu (tabel 1), pemanfaatan tersebut dapat dikatakan sudah maksimal, akan tetapi saat ini hanya sebagian orang saja yang masih memanfaatkan buah pinang sebagai ramuan makan sirih. Menurut masyarakat tradisional tradisi makan sirih dapat memperkuat gigi, sehingga banyak terlihat orang tua yang giginya masih kuat (Silvia et al, 2017).

Tumbuhan Arecaceae selanjutnya yang ditemukan yaitu Palem (Chrysalidocarpus lutescens). Di kota Tarakan jenis tumbuhan ini pemanfaatannya hanya sebatas tanaman hias (Tabel 1). Menurut Silvia et al (2017), menyatakan bahwa palem adalah tanaman yang biasanya dijadikan tanaman hias yang ditanam dipekarangan rumah, selain bentuk yang indah tanaman ini juga tidak mudah terkena penyakit dan mudah untuk tumbuh.

Jenis lain dari Arecaceae yaitu Aren (Arenga pinnata). A. pinnata merupakan tumbuhan berbiji tertutup (Angiospermae) yaitu biji buahnya terbungkus daging buah. Tanaman aren banyak terdapat mualai dari Pantai timur India sampai ke Asia Tenggara. Di Indonesia tanaman ini banyak terdapat hampir di seluruh wilayah Nusantara. Umur pohon aren mencapai lebih dari 50 tahun, dan diatas umur ini pohon aren suda sangat berkurang dalam memproduksi buah, bahkan sudah tidak mampu lagi memproduksi buah (Sunanto, 1993). Sebagian besar pemanfaatan A. pinnata di kota Tarakan yaitu dijadikan makanan dan minuman seperti gula, kolang kaling, dan tuak (tabel 1). Bagian buah aren yang muda dapat digunakan sebagai bahan campuran minuman dan kolak.Berdasarkan hasil wawancara buah aren yang dijadikan kolang-kaling (enau) adalah buah yang muda. Kolang-kaling pada umumnya dimanfaatkan oleh masyarakat sebagai bahan campuran makanan dan minuman, antara lain dalam pembuatan minuman buah, manisan kolang-kaling, dan pembuatan kolak. Tuak diolah secara tradisional dari fermentasi bunga mayang atau nira tanaman aren. Nira aren yang sudah ditampung tersebut dimasak, sebelum air nira mendidih dimasukan kulit kayu damar yang bertujuan mencegah nira tidak menjadi masam, tidak terlalu manis dan pahit. Arak atau tuak yang dimasak dapat bertahan lama jika dibandingkan dengan arak yang tanpa dimasak (Nuryanti et al. 2015).Selain itu Menurut Irawan dkk (Roswati, 2018), tangkai daun aren yang dibakar dapat menghasilkan obat tradisional yaitu sarerang kawung yang berfungsi sebagai bahan kosmetik, menghilangkan bekas jerawat, bekas cacar, luka bakar dan juga dipercaya dapat menghaluskan kulit.Menurut Oktavia (2017),gula aren yang berasal dari nira tandan bunga digunakan sebagai bahan campuran parem untuk obat penyakit kulit.

Selain C. nucifera, A. catechu, C. lutescens, dan A. pinnata, di kota Tarakan juga dijumpai kelapa sawit (Elaeis gulneensis). Elaeis gulneensis di kota Tarakan masih belum dimanfaatkan secara maksimal, hanya sebatas dijadikan pakan ternak dan sebagai tanaman hias (tabel 1). Menurut Nuryanti et al (2015) E. gulneensis juga dapat dimanfaatkan sebagai bahan bangunan, batang kelapa sawit dapat dijadikan papan untuk membuat rumah, dan buah tandan dimanfaatkan sebagai minyak kelapa sawit diantaranya sebagai bahan industry pangan dan non pangan. Menurut masyarakat Seulimum buah kelapa sawit yang sudah tua juga bisa diolah menjadi minyak makan, buah kelapa sawit pada waktu muda berwarna hitam, kemudian setelah berumur kurang lebih lima bulan berangsur-angsur menjadi merah kekuningan, pada saat perubahan warna tersebut terjadi proses pembentukan minyak pada daging buah. Perubahan warna tersebut terjadi karena pada butir-butir minyak mengandung zat warna (Nurmaliah dan Idatia, 2011).

Tumbuhan terakhir yang ditemukan adalah jenis salak (Zalaca edulis).Tanaman salak merupakan tanaman yang banyak jenisnya, dan rasanya yang beraneka ragam, sehingga banyak masyarakat yang membudidayakan dan bahkan ada masyarakat yang memiliki 


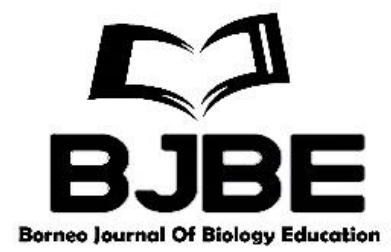

perkebunan salak yang sangat luas.Bagian tanaman yang dapat dimanfaatkan adalah bagian buah untuk di mmakan. Z. edulis di kota Tarakan oleh masyarakat hanya dimanfaatkan buahnya baik itu dimakan langsung maupun dibuat manisan. Sebagian masyarakat kota Tarakan juga menggunakan pelepah tanaman ini untuk dijadikan sebagai joran pancing tradisional.Menurut (Wijaya et al., 2005 dalam Joshua 2018) buah salak dapat dimanfaatkan dalam hal pewangi.Menurut (Wijanarti et al., 2015 dalam Joshua 2018) masing-masing jenis salak mempunyai bau yang khas yang dapat dijadikan sebagai pewangi.Penelitian Wijanarti et al., 2015 menunjukan bahwa ekstrak kulit salak bermanfaat untuk meningkatkan sistem kekebalan tubuh.

Pemanfaatan jenis tumbuhan family Arecaceae di kota Tarakan secara tradisional sudah jarang ditemukan seperti tradisi makan sirih. Harusnya tradisi seperti itu harus tetap ada di zaman modern ini agar nilai-nilai yang terkandung baik dari segi budaya dan kesehatan tetap terjaga (Winda, et al,2015).

\section{Kesimpulan}

Berdasarkan Hasil dan Pembahasan dapat disimpulkan bahwa Family Arecaceae yang ditemukan di kota Tarakan adalah Cocus nucifera, Areca catechu, Chrysalidocarpus lutescens, Elaeis gulneensis, Arenga pinnata, Zalaca edulis. Tumbuhan tersebut di masyarakat kota Tarakan dimanfaatkan sebagai bahan pangan, obat tradisional seperti obat alergi/ keracunan, obat sakit kepala, bahan bangunan, anyaman, kerajinan tangan, tanaman hias, karya seni dan obat-obatan. Sehingga dapat disimpulkan bahwa family Arecaceae di Kota Tarakan memiliki manfaat bagi masyarakat baik itu dari segi kesehatan, budaya dan ekonomis. Akan tetapi pemanfaatan dari Arecaceae di kota Tarakan masih terbilang standar dan bahkan ada yang sudah mulai berkurang seperti pemanfaatan buah pinang sebagai ramuan makan sirih.

\section{Ucapan Terima Kasih}

Penulis mengucapkan terimakasih kepada seluruh masyarakat Kota Tarakan yang telah membantu kami dalam proses pengambilan data dan bersedia menjadi responden untuk memberikan informasi terkait pemanfaatan family Arecaceae serta rekan-rekan mahasiswa Pendidikan Biologi pengampu mata kuliah Metode Penulisan Karya Ilmiah yang turut berkontribusi dalam terlaksananya penelitian ini.

\section{Daftar Pustaka}

Badan Metorologi Klimatologi dan Geofisika Kota Tarakan.

Hakim, L. (2014). Etnobotani Dan Manajemen Kebun Pekarangan Rumah: Ketahanan Pangan, Kesehatan Dan Agrowisata. Malang: Penerbit Selaras.

Joshua, J., \& Sinuraya, R. K. (2018). Keanekaragaman Aktivitas Farmakologi Tanaman Salak (Salacca Zalacca). Farmaka, 16(1), 99-107. 


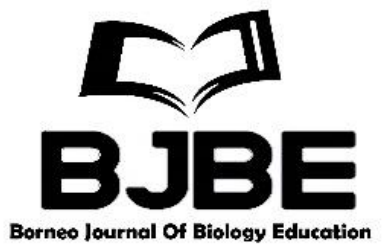

Vol. 2 No. 1, 2020; pp. 16-23

P-ISSN: 2715-6826 (print); E-ISSN: 2714-6073 (online)

Received: $3 / 01 / 2020$

Revised: $27 / 02 / 2020$

Accepted: 5/03/2020

Listiani, L., \& Abrori, F.M. (2017). Kajian Folk Taxonomy dalam Penelitian Etnobotani (Studi Kasus Taksonomi Rakyat pada Beberapa Suku di Indonesia). Yogyakarta: Penebar Media Pustaka

Nurmaliah, C. dan Restiani, C. (2011). Etnobotani Familia Arecaceae di Kaabupaten Aceh Barat Daya. Prosiding Seminar Nasional Biologi. Sumatera Utara: USU Press.

Nuryanti, S., Linda, R., \& Lovadi, I. (2015). Pemanfaatan Tumbuhan Arecaceae (PalemPaleman) Oleh Masyarakat Dayak Randu'Di Desa Batu Buil Kecamatan Belimbing Kabupaten Melawi. Protobiont, 4(1):: 128-135.

Oktavia, G. A. E., Darma, I. D. P., \& Sujarwo, W. (2017). Studi etnobotani tumbuhan obat di kawasan sekitar Danau Buyan-Tamblingan, Bali. Buletin Kebun Raya, 20(1), 1-16.

Pratiwi, F. M., \& Sutara, P. K. (2013). Etnobotani kelapa (Cocos nucifera L.) di wilayah Denpasar dan Badung. Jurnal Simbiosis, 1(2), 102-111.

Roswita, C. (2018). Pemanfaatan Tumbuhan Palem-Paleman (Arecaceae) Sebagai Obat Tradisional Oleh Masyarakat Aceh Di Kecamatan Gandapura Kabupaten Bireuen. Jurnal Biosains, 4(1), 32-38.

Silvia, Y. (2017). Etnobotani Tumbuhan Anggota Arecaceae Di Kecamatan Seulimum. Jurnal Ilmiah Mahasiswa Fakultas Keguruan dan Ilmu Pendidikan Unsyiah 2(2), $30-42$.

Siregar, EBM. (2005). Potensi Palem Indonesia.USU PRESS.Sumatera.

Sunanto, H. (1993). Aren Budidaya dan Multiguna.Yogyakarta: Kanisius.

Winda, G. W., Budhi, S., \& Sisillia, L. (2016) Etnobotani Masyarakat Desa Saham (Studi Kasus di Desa Saham, Kecamatan Sengah Temila Kabupaten Landak, Kalimantan Barat). Jurnal Hutan Lestari, 4(1).

Tjitrosoepomo, G. (1983). Botani Umum3. Bandung: Penerbit Angkasa 